Удк 332.146.2

DOI https://doi.org/10.32851/2708-0366/2021.6.7

Карташова О.Г.

кандидат економічних наук, доцент, Херсонський державний аграрно-економічний університет ORCID: https://orcid.org/0000-0002-9692-7032

Kartashova Olga

Kherson State Agrarian and Economic University

\title{
ПРОБЛЕМИ ТА ПЕРСПЕКТИВИ РОЗВИТКУ ВИРОБНИЦТВА ТА ПЕРЕРОБКИ СІЛЬСЬКОГОСПОДАРСЬКОЇ ПРОДУКЦІЇ НА РЕГІОНАЛЬНОМУ РІВНІ НА ПРИКЛАДІ ХЕРСОНСЬКОЇ ОБЛАСТІ
}

\author{
PROBLEMS AND PROSPECTS FOR DEVELOPMENT \\ OF PRODUCTION AND PROCESSING OF AGRICULTURAL PRODUCTS \\ AT THE REGIONAL LEVEL ON THE CASE OF KHERSON OBLAST
}

У статті визначено проблеми та перспективи розвитку виробництва та переробки сільськогосподарської продукиії на регіональному рівні на прикладі Херсонської області. Проаналізовано рівень заробітної плати мешканців Херсонської області, структуру використання земель с/2 Херсонської області, основні економічні показники виробництва та переробки сільськогосподарської продукиії, матеріально-технічний стан підприємств Херсонської області та його модернізацї. Сформульовано основні проблеми, які гальмують розвиток сільського господарства України. Визначено, щзо для вирішення проблем у сільському господарстві та промисловості регіону, для Херсонської області може бути доиільним створення комунального підприємства. Сформовано основні засади проектування та реалізації з впровадження проекту створення комунального підприємства, яке стане иентром для виробників та переробників сільськогосподарської продукиії для створення продукиії с високою доданою вартістю.

Ключові слова: сільськогосподарська продукиія, регіон, сільське господарство, додана вартість, комунальне підприємство.

В статье определены проблемы и перспективы развития производства и переработки сельскохозяйственной продукции на региональном уровне на примере Херсонской области. Проанализирован уровень заработной плать жстелей Херсонской области, структуру использования земель с/х Херсонской области, основные экономические показатели производства и переработки сельскохозяйственной продукичи, материально-техническое состояние предприятий Херсонской области и его модернизации. Сформулировань основные проблемы, которые тормозят развитие сельского хозяйства Украины. Определено, что для решения проблем в сельском хозяйстве и промышленности региона, для Херсонской области может быть иелесообразным создание коммунального предприятия. Сформированы основные принципь проектирования и реализации по внедрению проекта создания коммунального предприятия, которое станет иентром для прочзводителей $и$ переработчиков сельскохозяйственной продукции для создания продукции с высокой добавленной стоимостью.

Ключевые слова: сельскохозяйственная продукиия, регион, сельское хозяйство, добавленная стоимость, коммунальное предприятие.

The article identifies problems and prospects for the development of production and processing of agricultural products at the regional level on the example of Kherson region. It is determined that the main directions of development of the agricultural sector of the region are to increase production and deepen processing, create added value of agricultural products, export orientation and sale of agricultural products directly by producers to non-resident companies without the participation of traders registered in Ukraine; diversification of production, both in crop and livestock production and popularization and development of organic production and 
small-scale farming. The level of wages of residents of Kherson region, the structure of agricultural land use in Kherson region, the main economic indicators of production and processing of agricultural products, material and technical condition of enterprises of Kherson region and its modernization are analyzed. It is determined that the reasons for the underdevelopment of the processing industry are: outdated existing equipment; lack of qualified personnel for processing enterprises; imperfect and outdated production technologies; product quality does not meet the needs of consumers; low level of competitor at her food. The main problems that hinder the development of agriculture in Ukraine are formulated. The experience of European countries in overcoming the crisis in agriculture has been studied. The state priorities of financial support of the country's agricultural development are determined. It is determined that to solve problems in agriculture and industry of the region, for the Kherson region it may be appropriate to create a utility company. The basic principles of design and implementation of the project to create a utility company, which will become a center for producers and processors of agricultural products to create products with high added value. The project will provide an opportunity to provide: increase jobs in the field of agricultural processing; high quality products that meet international standards; sustainability of the agrarian business environment; rural development; increasing the level of entrepreneurial activity.

Key words: agricultural products, region, agriculture, value added, communal enterprise.

Постановка проблеми. В Україні особливу роль в соціальному та економічному житті відіграє сільське господарство та весь аграрний сектор економіки. Він характеризується унікальним поєднанням сприятливих природних умов і геостратегічним розташуванням, здатністю нашої країни використовувати свій природно-ресурсний потенціал, що сприяє можливості зайняти вигідне місце на світовому ринку продовольства, енергетики та інших. Сільськогосподарська діяльність в Україні є стратегічним сектором виробництва, який представлено в усіх регіонах країни. В свою чергу, державна підтримка має бути направлена на створення умов для ефективного розвитку в пріоритетні галузі з урахуванням економічних, соціальних та екологічних стимулів, збільшення кількості випущеної продукції сільського господарства, підвищення конкурентоспроможності виробників сільськогосподарської продукції, підвищення якості життя населення. Зростання цін на сільськогосподарську продукцію в світі створює унікальні можливості для швидкого розвитку складових агропромислового комплексу в Україні, про що свідчить зростання цін на світовому ринку продовольства протягом 2018-2019 років. Таким чином, такі умови створюють значні переваги для головних експортерів сільськогосподарської продукції на світовому ринку, де Україна може зайняти своє місце, а також може вирішити глобальні продовольчі проблеми на партнерських умовах.

Аналіз останніх досліджень і публікацій. Аналізуючи різноманітні підходи до формування теоретичних підходів інноваційних процесів, можна відзначити роботи В. Геєць, С. Покропивного, П. Саблука, Р. Фатхутдинова, А. Шестопал та інші. Дослідженнями Проблем державного регулювання, матеріального, фінансового та інформаційного забезпечення інноваційної діяльності й розвитку інноваційних процесів в агропромисловому виробництві приділяли увагу вчені: Іванишин В. В., Могильна Л. М., Крисанов Д. Р., Кузнєцова А. Я. Дослідженнями ідей кластерних видів об'єднань займалися М. Портер, А. Маршалл, А. Вебер, Ф. Котлер. Однак, незважаючи на великий науковий та практичний інтерес до оцінки сформованого потенціалу та рівня розвитку сільськогосподарських підприємств, потребують подальших досліджень питання розвитку підприємств, що займаються виробництвом та переробкою сільськогосподарської продукції, на базі публічно-приватного партнерства.

Формулювання цілей статті. Метою статті $є$ дослідження проблем та пошук перспектив розвитку виробництва та переробки сільськогосподарської продукції на регіональному рівні на прикладі Херсонської області.

Виклад основного матеріалу. В умовах ринкової економіки успіх підприємств залежить від раціонального використання його потенціалу. Потенціал формується під безпосереднім впливом факторів внутрішнього і зовнішнього середовища, які орієн- 
тують регіон на досягнення довгострокових цілей розвитку у відповідності з наявним ресурсним забезпеченням. Ефективність використання потенціалу регіону визначає результативність дії довгострокових цілей та потребує принципово нових підходів до формування його економічного потенціалу.

Для отримання інформації щодо оцінки сформованого потенціалу (технічного, технологічного, біологічного, кадрового, організаційного, екологічного, соціального, економічного, інноваційного, управлінського) та рівня розвитку сільськогосподарських підприємств, що займаються виробництвом та переробкою сільськогосподарської продукції, було проведено дослідження на рівні Херсонської області.

Раціональне використання трудового потенціалу відіграє важливу роль у підвищенні ефективності суспільного виробництва та рівня життя населення. Тому від того, наскільки раціонально він сформований, багато в чому залежить економічний потенціал кожного виду економічної діяльності, темпи його розвитку, зростання соціального і культурного рівня життя найманих працівників та роботодавців, становлення повноцінних відносин соціального партнерства [1].

В Херсонській області в області проживає понад 500 тис. економічно активного населення, 3 них 201,1 тис. осіб - це сільське населення (40,2\%). Кількість економічно активного населення, що зайняте у сільському господарстві представлено на рис. 1.

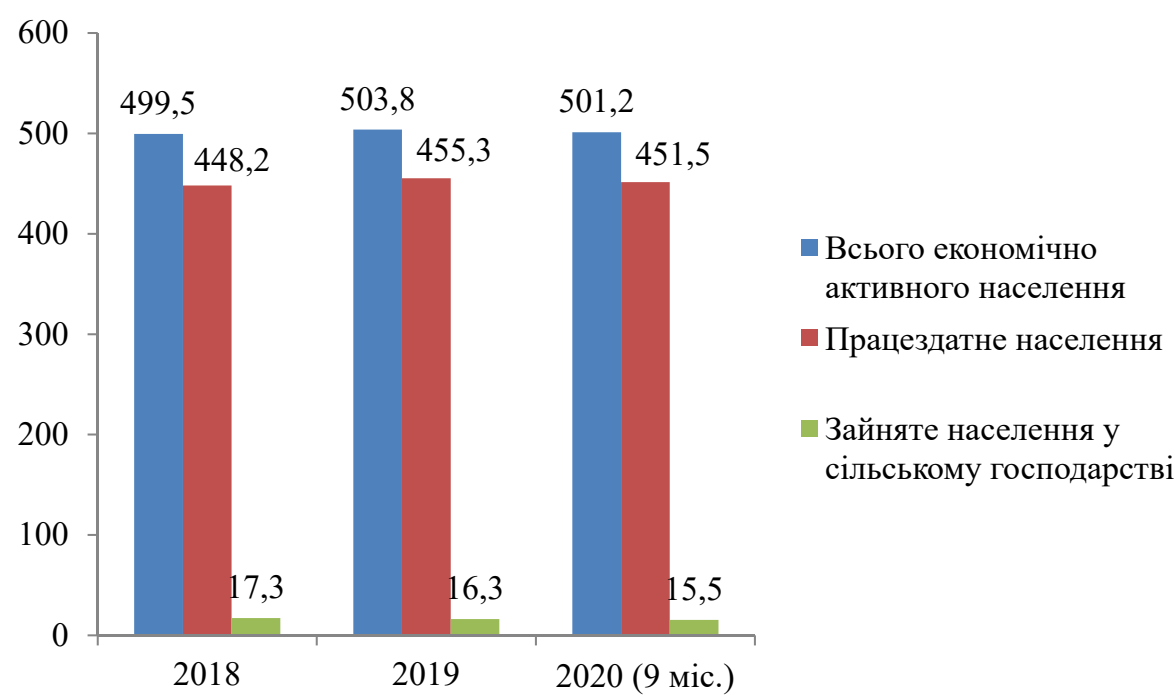

Рис. 1. Зайнятість сільського населення Херсонської області, тис. осіб [3]

За 9 місяців 2020 року середньомісячна заробітна плата у сільському господарстві складає 7875 грн у 1,6 рази вище рівня мінімальної заробітної плати (5000 грн), але менша на 1123 грн за середню заробітну плату в цілому по області. За галузями вирощування сільськогосподарської продукції та їі переробкою рівень заробітної плати мешканців Херсонської області визначено на рис. 2.

Ефективне використання земельних угідь $є$ потужним чинником розвитку економіки усіх землекористувачів нашої країни. Подальше підвищення ефективності використання земельних ресурсів обумовлено нагальною потребою забезпечення виробництва конкурентоспроможної сільськогосподарської продукції у ринковому середовищі, якісного харчування населення України та збільшення обсягу реалізації продукції на зовнішньому ринку [5]. 


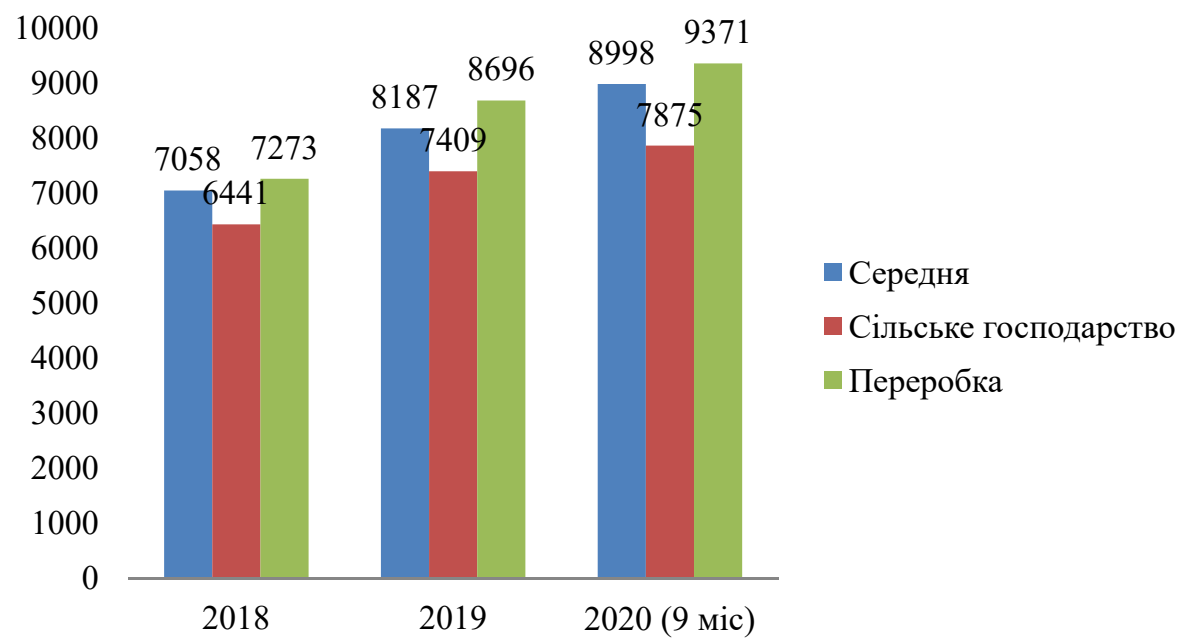

Рис. 2. Рівень заробітної плати мешканиів Херсонської області, грн [3]

У 2020 році Херсонська область налічує 1969,0 тис. га сільськогосподарських угідь, у тому числі 1777,0 тис. га ріллі. Вся посівна площа с/г культур складає 1417,9 тис. га. За групами культур структуру використання земель Херсонської області зображено на рис. 3.

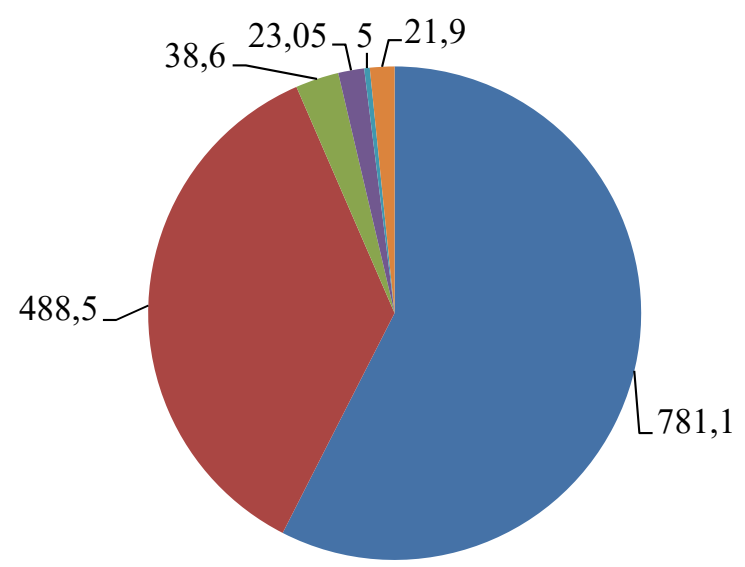
— Зернові та зернобобові кільтури

- Технічні культури

пвочеві

- Баштанні

- Кормові

- Картопля

Рис. 3. Структура використання земель с/2 Херсонської області у 2020, тис. га [3]

Аналізуючи структуру посівної площі сільськогосподарських культур в Херсонській області, більше половини земель, а саме 55\% зайнято під виробництво зернових та зернобобових культур. Третину угідь зайнято під виробництво технічних культур, решта питомою вагою до 5 \% кожної культури належить виробництву кормових, овочевих, баштанних культур та картоплі (рис. 4).

За 10 місяців 2020 року обсяги валової продукції сільського господарства в постійних цінах 2016 року по області складають 25235,5 млн грн., у тому числі продукції рослинництва - 22116,3 млн грн., тваринництва - 3119,3 млн грн.

Основними напрямками розвитку аграрної галузі області є збільшення обсягів виробництва і поглиблення переробки, створення додаткової вартості сільськогосподарської продукції, експортна орієнтація і продаж сільськогосподарської продукції 
безпосередньо виробниками компаніям-нерезидентам без участі трейдерів, зареєстрованих в Україні; диверсифікація виробництва, як в рослинництві, так і в тваринництві та популяризація і розвиток органічного виробництва та дрібного фермерства. Зважаючи на економічні результати діяльності сільськогосподарських підприємств, формування попиту та споживання сільськогосподарської продукції, доцільніше розширювати виробництво овочевої продукції на території Херсонської області [7].

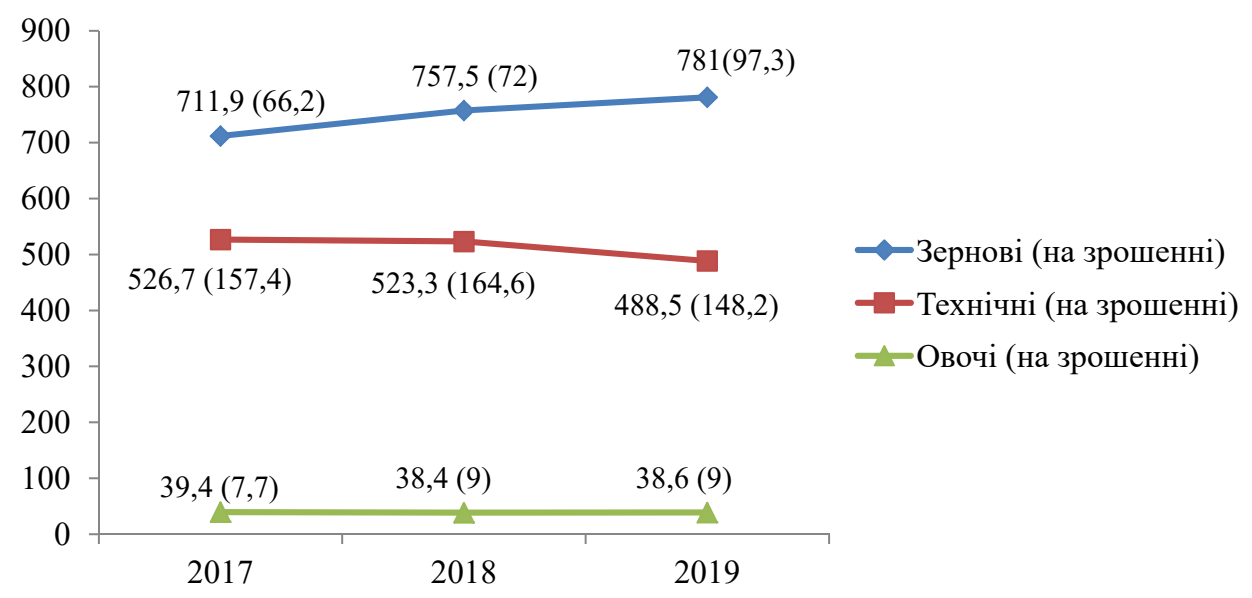

Рис. 4. Динаміка використання земель с/2 призначення Херсонської області, тис. га [3]

Виробництво овочів є однією з головних складових виробництва сільськогосподарської продукції в Україні, а також Продовольча та сільськогосподарська організація ООН (ФАО) визнала Україну як перспективного світового донора продуктів харчування, включаючи овочеві культури. Херсонська область займає перше місце серед регіонів України за рівнем виробництва овочів, частка якого становить близько $14 \%$ загальнодержавного обсягу виробництва сільськогосподарських культур. Левова частка овочівництва припадає на райони з розвиненою мережею зрошувальних систем.

Для забезпечення внутрішнього ринку споживання свіжими овочевими продуктами та для експорту їх за кордон, необхідно створити транспортний та логістичний комплекс, функція якого полягає у формуванні попиту на овочеву продукцію, оптимізувати транспортні потоки, операції з обробки, контролю та гарантування продукції якості та формування оптових партій для продажу, стабілізування цінової політики на українському овочевому ринку. У майбутньому такі комплекси зможуть виконувати роль замовників обсягів овочевої продукції на контрактній основі [7].

Незважаючи на те, що відбулись зміни у формах господарювання, ці глобальні перетворення, на превеликий жаль, не в повній мірі виправдали покладені на них надії. Саме через ці обставини у сучасних умовах виникає об'єктивна необхідність у проведені досліджень діяльності існуючих форм господарювання в аграрному виробництві і на основі аналізу результатів функціонування різних організаційно-господарських структур виявити основні причини, що гальмували їх результативну діяльність, встановити тенденції та закономірності їх розвитку як у сучасних умовах, так і на перспективу.

На сьогоднішній день на території Херсонської області знаходиться 153 підприємства переробної та харчової галузі, з них хлібопекарські - 44 об'єкта; борошномельні - 22 об'єкта; оліє-жирові - 28 об'єкта; овочеконсервні - 10 об'єктів; виноробні - 7 об'єктів; молокопереробні - 10 об'єктів; м'ясопереробні - 11 об'єктів; кондитерські - 6 об'єктів; інші - 15. 
За 2015-2020 роки проведено модернізацію та реконструкцію тільки на 48 підприємствах, що становить $31,4 \%$ від загальної кількості підприємств, що катастрофічно малою кількістю для розвитку.

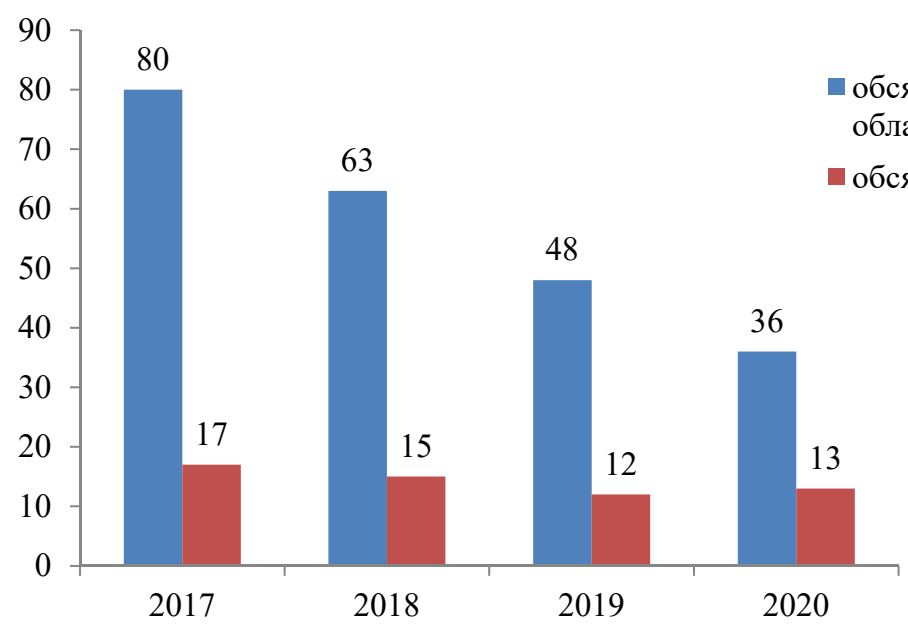

Рис. 5. Матеріально-технічний стан підприємств Херсонської області та його модернізаиія, $y \%$ [3]

Негативно впливає на обсяги виробництва, що виникає в процесі виробничого використання обладнання - моральна і фізична зношеність основних засобів.

Причини нерозвиненості галузі переробки: застаріле наявне обладнання; відсутність кваліфікованих кадрів для переробних підприємств; недосконалі та застарілі технології виробництва; якість продукції не відповідає потребам споживачів; низький рівень конкурентоорієнтованої харчової продукції.

Станом на 01 листопада 2020 року зібрано 1222,0 тис тонн овочів, що складає 99,7\% від попереднього року, з них направлено на переробні підприємства лише 20,9\%, 75,8\% - оптовим посередникам та роздрібній торговельній мережі, експортовано - 2,1\% та 1,2\% - на ринку, через власні магазини/кіоски. Підприємства майже не створюють продукт з високою доданою вартістю.

Слід зауважити, що більшість з асортименту продукції, що виробляється, відноситься до соціально значущих продовольчих товарів.

Через зменшення ринку збуту продукції до Криму, Росії, Сходу України у січнівересні 2020 року порівняно 3 аналогічним періодом минулого року по області на підприємствах із виробництва харчових продуктів, напоїв зменшився випуск. Також негативно впливає на обсяги виробництва, що виникає в процесі виробничого використання обладнання це моральна і фізична зношеність основних засобів.

До основних проблем, які гальмують розвиток сільського господарства України, належать:

1) Зношеність сільськогосподарської техніки. В раніше проведених дослідженнях доведено, що такий стан техніки сільського господарства $є$ одним із головних факторів (за виключенням несприятливих погодних умов), що призводить до значних втрат урожаю.

2) Скорочення обсягів інвестування в сільське господарство. Багато аграріїв відчувають проблеми, пов'язані з фінансуванням їх діяльності (як за обсягом, так і за умовами фінансування). 
3) Скорочення експорту аграрної продукції та сировини, що є наслідком стагнації зовнішніх ринків. Для України, яка має економіку, орієнтовану на експорт, у частці якого сільськогосподарська продукція займає майже 46 \%, це є дуже серйозним випробуванням.

4) Невирішеність питання щодо формування ринку землі сільськогосподарського призначення в Україні.

Серед проблем в сільському господарстві Херсонської області слід виокремити такі: відсутність робочих місць на селі; висока ціна продукції; незбалансованість раціону населення; рівень захворюваності та тривалості життя; низька якість продукції; велика кількість продукції без доданої вартості; відсутність доступних можливостей для розвитку; обмеженість доступних кредитів; старе обладнання для переробки.

На інвестиційну діяльність аграрних підприємств активно впливає держава через проведення кредитної та амортизаційної політики, надання фінансової допомоги у вигляді дотацій, субсидій і субвенцій, податкової політики. Іноземні інвестиції використовуються тоді, коли вітчизняне сільське господарство не в змозі забезпечити належного рівня виробництва товарів власними коштами. У сфері інвестиційної діяльності особливе місце займають фінансові інвестиції. Інвестування вільних коштів у фінансові інструменти (корпоративні права, цінні папери, деривативи тощо) ставить за мету одержання в майбутньому прибутку, установлення контролю над підприємством та інші цілі. Фінансові інвестиції можуть здійснюватися за такими напрямами як: інвестиційна діяльність по вкладенню коштів у фінансові інструменти і зокрема в цінні папери.

У скрутній економічній ситуації, яку переживало багато країн, у тому числі і Україна, зовнішні фінансові ресурси дуже часто $є$ найважливішим засобом розвитку сучасного сільського господарства. I на сучасному етапі значна частина машин, устаткування, обладнання і технологій, необхідних для виробництва надходячи у вітчизняну аграрну економіку з промислово розвинутих країн, причому забезпечується здебільшого зовнішнім фінансуванням. Фактична величина інвестицій аграрних підприємств залежить від його інвестиційного потенціалу [4].

Якщо звернутись до досвіду європейських країн, зокрема Англії, то там для фермерів існують державні дотації, їх виділяють у розрахунку 225 дол./га. Ця сума може змінюватись тільки через коливання валют - євро до англійського фунта. Щоб отримати субсидію, фермер мусить довести, що чітко виконує вимоги законодавства по захисту навколишнього середовища, мінімізації забруднення фосфатами та азотними добривами, показати свою професійність у землеробстві, дотриманні сівозміни, мінімізації ерозії грунтів тощо.

Для подолання кризових явищ в сільському господарстві, ряд країн запроваджував такі заходи на державному та регіональному рівнях:

- Німеччина функціонують кредитозберігальні сільські кооперативи;

- Польща - Агенція з реструктуризації та модернізації сільського господарства (АРМСГ);

- Великобританія - державно-кооперативні об'єднання, які побудовані по вертикально-інтегрованому типу з безперервним потоком товару від фермера до закупівельного кооперативу, далі на переробку, а потім до споживача або на експорт;

- Австрія - основними положеннями програми є: підтримка сільських територій через субсидії; переробки і збуту агропродуктів;

- Франція - кооперативи здійснюють кредитування фермерських господарств, постачання засобів виробництва, заготівлю, переробку, зберігання і збут продукції, а також підготовку необхідних кадрів, надають консультації. Кредитування сільського господарства забезпечують основним чином кооперативні банки. Кредити призначені для купівлі сільгосппідприємствами обладнання, худоби. Отримують кредити з нижчою відсотковою ставкою; 
- Канада - спеціалізовані лізингово-кредитні агентства підтримки дрібних фермерських господарств.

Враховуючи найкращий досвід країн для вирішення проблем у сільському господарстві та промисловості регіону, для Херсонської області може бути доцільним створення комунального підприємства.

Для розв'язання основної проблеми АПК і підвищення конкурентоспроможності вітчизняних агровиробників в Державній цільовій програмі розвитку аграрного сектору економіки на період до 2022 року, особливий акцент зроблено на впровадженні технологій та інновацій до аграрної сфери, а саме:

- запровадження в сільському господарстві принципу «точного землеробства» управління кожним квадратним метром землі;

- автоматизація обробки полів, посіву, внесення добрив, боротьби з бур'янами та шкідниками;

- заощадження кількості посівного матеріалу, добрив, засобів захисту рослин.

Основні напрямки з модернізації та технічного оснащення сільськогосподарських підприємств:

- великий обсяг наданих послуг з вітчизняним та закордонним обладнанням;

- стимулювання за рахунок створення школи новітніх технологій (навчання 3 супроводу обладнання);

- створення Інтернет товарної біржі, як логістичного центру виробленої продукції;

- пільгові умови постачання сучасного обладнання для переробки с/г продукції [6].

В ланцюжку створення доданої вартості продукту, особливо в органічному овочівництві, де у виробників Херсонщини є досить добрі шанси мати успіх, дуже важливим $\epsilon$ формування відносин між учасниками овочевого ринку на основі маркетингу взаємодії, підходах партнерства та спільної вигоди. Досягти цього можливо в рамках кластерної моделі, що на умовах кооперації забезпечить концентрацію маркетингових зусиль регіональних виробників на створення конкурентоспроможної овочевої продукції та ii затребуваність на ринку за рахунок використання елементів емоційного маркетингу. Учасниками - партнерами такої кластерної структури можуть виступити - місцеві органи влади, що зацікавлені в розвитку Херсонщини (обласна державна адміністрація, Департамент розвитку сільського господарства та зрошення), аграрні підприємства малого і середнього бізнесу та інтегровані об'єднання (агрохолдинги), що займаються овочевими культурами, переробні підприємства, транспортно-логістичні компанії, фінансові установи та інвестиційні компанії, дослідницькі та рекламні компанії, аграрні науково-дослідні установи, в тому числі ХДАЕУ як нова модель підприємницького університету та наукового аграрного бізнес-центр-інкубатору півдня України, підприємства суміжних галузей (готельно-ресторанна індустрія, туристично-рекреаційна сфера, в тому числі зелений та агротуризм, підприємства харчової галузі та громадського харчування, тощо), торгівельні підприємства та торгівельні мережі, представники громадськості та громадські організації (наприклад ГО «Земля Таврії», ГС «Таврійський туристичний альянс»), засоби масової інформації, телевізійні медіаканали та ін.

Кластерний підхід забезпечить агробізнесу Херсонщини ряд ключових переваг, а саме: завдяки задіянню у виробництві підприємств різної величини та різних форм власності вдасться досягти поєднання спеціалізації виробництва, з одного боку, та гнучкості цього процесу - 3 іншого; кластери дозволять нарощувати обсяги виробництва і надання послуг, завдяки цьому використати ефект «кривої досвіду» та зменшити витрати на виготовлення одиниці продукції та надання послуг; кластерна організація виробництва забезпечить ширше використання нових технологій; взаємодія підприємств у межах кластерів дозволить посилювати процеси спеціалізації і розподілу праці, розширювати міжорганізаційні потоки новацій та використовувати інно- 
ваційний потенціал більшої кількості працівників галузі овочівництва; розширення обсягів діяльності дозволить створювати нові робочі місця та посилювати соціальну відповідальність бізнесу щодо розвитку об'єднаних територіальних громад, їх інфраструктурних об'єктів та області в цілому; спрямованість багатьох підприємств на виробництво екологічної органічної продукції дозволить ефективніше використовувати місцеві природні ресурси області (коли виробники дотримуються схеми агрономічно-доцільних овочевих сівозмін, використовують системи живлення та догляду за рослинами без шкідливих домішок для забезпечення підвищення родючості грунту та збільшення врожайності культур та їх товарності, а сфера переробки овочевої продукції в своїй діяльності спирається на технології, що не мають негативних екологічних наслідків) [4].

Серед державних пріоритетів фінансового забезпечення розвитку сільського господарства країни $є$ : збільшення обсягів фінансової підтримки сільськогосподарської галузі; зниження рівня відсоткових ставок фермерів; розширення інструментів впливу на можливість доступу до фінансових ресурсів (механізми мікрокредитування, кредитна кооперації, збільшення обсягів державних закупівель сільськогосподарської продукції по форвардним контрактам тощо); підвищення ефективності використання фінансових ресурсів; збільшення термінів та джерел залучення фінансових ресурсів; формування інструментів та зрозумілих правил гри на ринку землі, формування Державного банку земель, а також моніторинг ринку земель для запобігання надмірної їхньої концентрації в одного власника.

В України доцільно більшою мірою залучати приватні інвестиції в агропромисловий комплекс внаслідок наявних фінансових обмежень.. Це в свою чергу потребує створення системи преференцій для приватного учасника ППП (публічно-приватного партнерства) у вигляді державних гарантів, пільгових кредитів, зменшення податкового навантаження [2].

На нашу думку, формування зв'язків в системі відносин в аграрному секторі Херсонської області потребує впровадження деяких змін, а саме створення комунального підприємства, яке стане центром для виробників та переробників сільськогосподарської продукції для створення продукції с високою доданою вартістю, де можуть бути залучені потужності для розміщення точок зростання (індустріальний парк) та навчальних можливостей (освітнього центру новітніх технологій) (рис. 6).

Мета проєкту:

- сприяння технічному переоснащенню та модернізації виробничих потужностей підприємств виробництва та переробки продукції сільського господарства з високою доданою вартістю;

- мотивація для відкриття сучасних переробних підприємств та модернізація існуючих;

- пошук цільових технологій, які можуть забезпечити модернізацію виробничих потужностей підприємств;

- постачання або надання в розстрочку викупу (лізинг) обладнання для виробництва;

- створення школи новітніх технологій для навчання з роботи з новим обладнанням для персоналу с-г. підприємств;

- мотивація до відновлення роботи підприємств, які виробляють обладнання.

Проєкт надасть можливість забезпечення: збільшення робочих місць у сфері переробки сільськогосподарської продукції; високої якості продукції, що відповідає міжнародним стандартам; сталості аграрного бізнес середовища; розвитку сільської місцевості; підвищення рівня підприємницької активності.

Проєкт націлений сприяти технічному переоснащенню та модернізації виробничих потужностей підприємств виробництва та переробки продукції сільського господарства з високою доданою вартістю. 


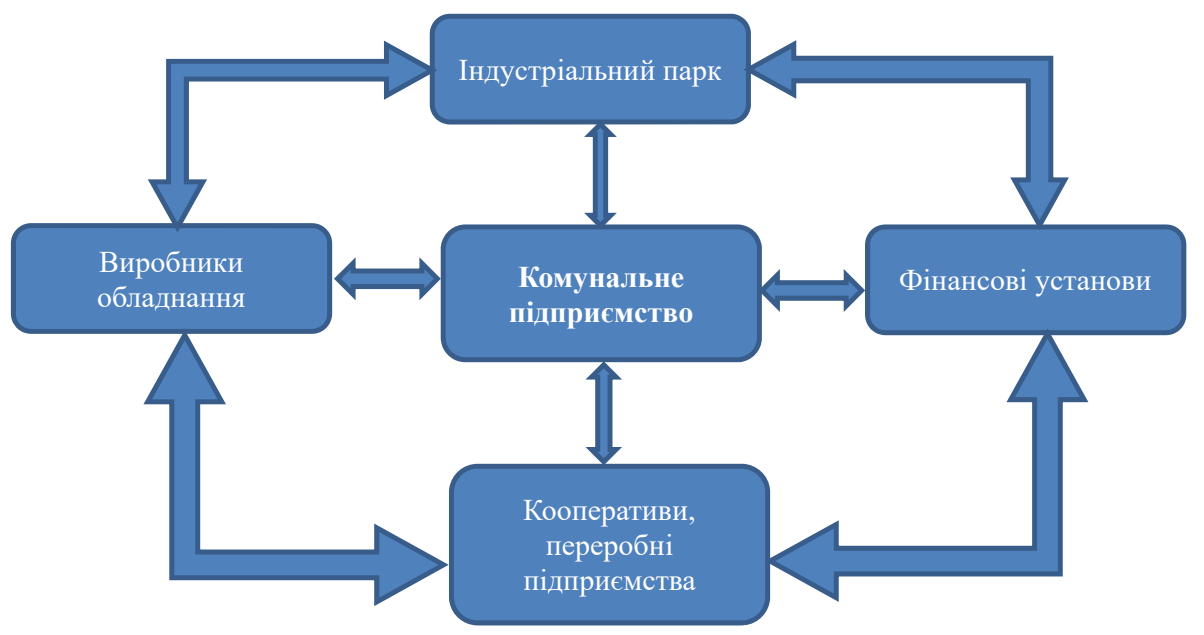

Рис. 6. Формування комунікаційних зв'язків в системі відносин в аграрному секторі за проєктом

Завдання, які може вирішити проект: пошук технологій, які можуть забезпечити модернізацію виробничих потужностей підприємств; постачання або надання в лізинг обладнання для виробництва; організація проведення навчань з роботи з новим обладнанням для персоналу с-г. підприємств.

Можливості, які може надати проект: збільшення робочих місць у сфері переробки сільськогосподарської продукції; високої якості продукції, що відповідає міжнародним стандартам; сталості аграрного бізнес середовища; розвитку сільської місцевості; підвищення рівня підприємницької активності.

Створення такого підприємства може передбачати такі етапи: прийняття депутатським корпусом рішення про створення КП; проведення реєстрації і призначення директора комунального підприємства; організація процедури із закупівлі матеріально-технічного, програмного забезпечення, меблів; організація процедури із пошуку зацікавлених підприємств, закупівля спеціалізованого обладнання надання в лізинг, допомога у пошуку спеціалізованого обладнання для підприємств; укладення договорів за основним видом діяльності.

Цільова аудиторія, на яку розраховано реалізацію проекту:

- підприємства, (середні та малі), фермери, ОСГ: які мають наявні лінії з переробки та потребують модернізації обладнання ; які планують займатися переробкою овочевої продукції;

- населення: в пошуках роботи на нових потужностях; в пошуках якісної регіональної переробленої продукції.

Ресурси, які можна залучити для створення проєкту: державні субвенції, цільові програми, можливість використання приватних ресурсів, фінансових ресурсів ДФРР та можливостей спільного фінансування.

Серед очікуваних результатів проєкту слід зазначити:

- зростання рівня кількості модернізованих підприємств щороку на 15-20\%;

- збільшення виробництва переробленої овочевої продукції сільського господарства Херсонської області на $10 \%$.

- збільшення кількості населення, зайнятого у сільському господарстві (вирощування овочів та їх переробка) на 28\%;

- збільшення ціни на овочеву продукцію на 25\% шляхом іiї переробки; 
- збільшення використання землі під вирощування овочів на 5\%;

- збільшення доходної частини бюджету всіх рівнів;

- збільшення кількості підприємств, які використовують сучасні технології 3 переробки продукції сільського господарства з високою доданою вартістю;

- якісна регіональна перероблена овочева продукція, що відповідає міжнародним стандартам;

- розвиток вітчизняних виробників сучасного обладнання;

- впровадження новітніх наукових розробок на виготовлення сучасного обладнання, що відповідає вимогам переробників;

- можливість збільшення обсягу експорту переробленої овочевої продукції 3 високою доданою вартістю;

- збільшення кількості робочих місць сільських територій у сфері переробки;

- розвиток сільської місцевості Херсонської області.

Висновки. Враховуючи, що український аграрний бізнес має величезні ресурси та перспективи ефективного розвитку, а за підтримки держави, процесів реформування та залучення банківської сфери, науковців та інвестиційних фондів до розвитку вітчизняного агропромислового комплексу, процес становлення позитивної динаміки АПК вийде на новий високий рівень, тим самим надасть можливість збільшити виробництво та продаж сільськогосподарської продукції в зарубіжних країнах, що сприятиме підвищенню конкурентоспроможності вітчизняної сільгосппродукції на міжнародному ринку та економічному розвитку України в цілому.

\section{Список використаних джерел:}

1. Губа М.І., Карташова О.Г., Оленковська Л.П. Сільський розвиток у системі реформування децентралізації влади. Теорія та практика державного управління і місиевого самоврядування. Місиеве самоврядування. 2020 № 1. DOI: 10.35546/kntu2308-8834/2020.1.32. URL: http://el-zbirn-du.at.ua/2020_1/34.pdf.

2. Губа М.І., Карташова О.Г. Розвиток сільських територій через публічно-приватне партнерство. Державне управління: удосконалення та розвиток. 2019. № 4. DOI: 10.32702/ 2307-2156-2019.4.21. URL: http://www.dy.nayka.com.ua/?op=1\&z=1414.

3. Державна служба статистики України. URL: http://www.ukrstat.gov.ua (дата звернення: 20.03.2021)

4. Кирилов Ю. Формування ефективного організаційно-економічного механізму інвестування аграрного сектору економіки України. Таврійський науковий вісник. Серія: Економіка. 2020. № 1. C. 36-45. URL: http://www.tnv-econom.ksauniv.ks.ua/index.php/journal/article/view/5.

5. Ксьонжик І.В., Потравка Л.О., Замковий В.М. Соціально-економічний розвиток територіальних громад в Україні в контексті децентралізації. Державне управління: удосконалення та розвиток. 2020. № 11. DOI: 10.32702/2307-2156-2020.11.3. URL: http://www.dy.nayka.com.ua/ ?op $=1 \& \mathrm{z}=1843$.

6. Переробна промисловість регіонів України: проблеми та перспективи розвитку : монографія; ДУ «Інститут регіональних досліджень імені М.І. Долішнього НАН України»; наук. редактор д.е.н., проф. С.О. Іщук. Львів, 2020. 341 с. (Серія «Регіони: моніторинг, прогнози, моделі»)

7. Boiko L.A. Logistics and production potential in the vegetable farming industry of the southern region of Ukraine. Erbe der europäischen wissenschaft: wirtschaft, management, tourismus, rechtsprechung. Monografische Reihe «Europäische Wissenschaft». Buch 2. Teil 5. 2020. P. 106-113.

\section{References:}

1. Guba M.I., Kartashova O.G., Olenkovs'ka L.P. (2020) Sil's'kij rozvitok u sistemi reformuvannya decentralizaciï vladi [Rural development in the decentralization reform system]. Teoriya ta praktika derzhavnogo upravlinnya i miscevogo samovryaduvannya. Misceve samovryaduvannya, no. 1. DOI: 10.35546/kntu2308-8834/2020.1.32. Available at: http://el-zbirn-du.at.ua/2020_1/34.pdf.

2. Guba M.I., Kartashova O.G. (2019) Rozvitok sil's'kih teritorij cherez publichno-privatne partnerstvo [Development of rural areas through public-private partnership]. Derzhavne 
upravlinnya: udoskonalennya ta rozvitok, no. 4. DOI: 10.32702/2307-2156-2019.4.21. Available at: http://www.dy.nayka.com.ua/?op=1\&z=1414.

3. Derzhavna sluzhba statistiki Ukraïni Available at: http://www.ukrstat.gov.ua (accessed 20 March 2021).

4. Kirilov Yu. (2020) Formuvannya efektivnogo organizacijno-ekonomichnogo mekhanizmu investuvannya agrarnogo sektoru ekonomiki Ukraïni [Formation of effective organizational-economic mechanism of investment agricultural sector of Ukraine]. Tavrijs'kij naukovij visnik. Seriya: Ekonomika, no.1, pp. 36-45. Available at: http:/www.tnv-econom.ksauniv.ks.ua/index.php/journal/ article/view/5.

5. Ks'onzhik I.V., Potravka L.O., Zamkovij V.M. (2020) Social'no-ekonomichnij rozvitok teritorial'nih gromad v Ukraïni v konteksti decentralizacii [Socio-economic development of territorial communities in Ukraine in the context of decentralization]. Derzhavne upravlinnya: udoskonalennya ta rozvitok, no. 11. DOI: 10.32702/2307-2156-2020.11.3. Available at: http://www.dy.nayka.com.ua/ ?op $=1 \& \mathrm{z}=1843$.

6. Pererobna promislovist' regioniv Ukraïni: problemi ta perspektivi rozvitku (2020) [Processing industry of the regions of Ukraine: problems and prospects of development] monografiya; DU "Institut regional'nih doslidzhen' imeni M.I. Dolishn'ogo NAN Ukraïni”; nauk. redaktor d.e.n., prof. S. O. Ishchuk. L'viv, 341 s. (Seriya "Regioni: monitoring, prognozi, modeli”).

7. Boiko L.A. (2020) Logistics and production potential in the vegetable farming industry of the southern region of Ukraine. Erbe der europäischen wissenschaft: wirtschaft, management, tourismus, rechtsprechung. Monografische Reihe «Europäische Wissenschaft». Buch 2. Teil 5. R. 106-113. 